\title{
Are Daycare Workers at a Higher Risk of Parvovirus B19 Infection? A Systematic Review and Meta-Analysis
}

\author{
Karla Romero Starke ${ }^{1, *}$, Marlen Kofahl ${ }^{1}$, Alice Freiberg ${ }^{1}$, Melanie Schubert ${ }^{1}{ }^{1}$, \\ Mascha Luisa Groß ${ }^{1}$, Stefanie Schmauder ${ }^{1}$, Janice Hegewald ${ }^{1}$, Daniel Kämpf ${ }^{1}$, \\ Johanna Stranzinger ${ }^{2}$, Albert Nienhaus ${ }^{2,3}$ and Andreas Seidler ${ }^{1}$ \\ 1 Institute and Policlinic of Occupational and Social Medicine (IPAS), Faculty of Medicine Carl Gustav Carus, \\ Technische Universität Dresden, 01307 Dresden, Germany; marlen.kofahl@tu-dresden.de (M.K.); \\ alice.freiberg@tu-dresden.de (A.F.); melanie.schubert@tu-dresden.de (M.S.); \\ mascha1806@gmail.com (M.L.G.); stefanie.schmauder@tu-dresden.de (S.S.); \\ janice.hegewald@tu-dresden.de (J.H.); Daniel.Kaempf@mailbox.tu-dresden.de (D.K.); \\ andreas.seidler@mailbox.tu-dresden.de (A.S.) \\ 2 Section Occupational Health, Basic Principles of Prevention and Rehabilitation, Institution for Statutory \\ Social Accident Insurance and Prevention in the Health Care and Welfare Services (BGW), \\ 22089 Hamburg, Germany; Johanna.Stranzinger@bgw-online.de (J.S.); \\ Albert.Nienhaus@bgw-online.de (A.N.) \\ 3 Competence Centre for Epidemiology and Health Services Research for Healthcare Professionals (CVcare), \\ University Medical Centre Hamburg-Eppendorf (UKE), 20251 Hamburg, Germany \\ * Correspondence: karla.romero_starke@tu-dresden.de; Tel.: +49-(0)173-450-4671
}

Received: 27 March 2019; Accepted: 15 April 2019; Published: 17 April 2019

\begin{abstract}
Objective: In this systematic review, we aimed to summarize the evidence on the association between being a daycare educator working with children and the possible increased risk of parvovirus B19 infection compared to the general population. Methods: The Medline and Embase databases were searched using a defined search to find studies published since 2000. Two reviewers evaluated the search hits using predefined inclusion and exclusion criteria. The resulting studies were extracted and were assessed in eight domains of bias. A pooled relative risk (RR) of parvovirus infection for daycare workers compared to the general population was calculated. Results: After evaluating the 7781 search hits and manual search, four methodologically-adequate studies were identified: three cross-sectional studies and one retrospective cohort study. Of the three studies investigating the risk of infection, one evaluated parvovirus B19 seroconversion rates for daycare workers. There was an indication for an increased risk for daycare workers compared to the unexposed population $(\mathrm{RR}=1.12,95 \% \mathrm{CI} 0.98-1.27)$ using prevalence estimators. Furthermore, daycare workers had a higher seroconversion rate compared to the unexposed population ( $R R=2.63,95 \%$ CI $1.27-5.45)$ in the low risk of bias study. Conclusions: Our findings suggest a higher risk of parvovirus B19 infection for daycare workers compared to an unexposed comparison population, which necessitate preventative efforts. Considering the underestimation of the occupational seroconversion risk by prevalence-based estimators, parvovirus B19 infections among daycare workers might mostly be occupationally acquired.
\end{abstract}

Keywords: parvovirus B19; fifth disease; daycare workers; daycare; kindergarten teachers; occupational risk; occupational disease 


\section{Introduction}

Infection of parvovirus B19 is mostly asymptomatic in children and teenagers, but the "fifth disease" can be the clinical presentation of infection. It is characterized by fever and malaise early in the infection, and by a "slapped-cheek" rash and rheumatic symptoms two weeks after infection, when the appearance of antiviral antibodies occurs [1]. However, infection in women of childbearing age deserves additional attention due to its potentially harmful effects on pregnant women and their fetus. It has been reported that $1-5 \%$ of pregnant women are affected by the parvovirus B19 infection [2]. About half of fetal infections are asymptomatic [3], but infection with parvovirus B19 during pregnancy, especially during the first two trimesters, has been associated with a risk of miscarriage, intrauterine fetal death, fetal anemia and non-immune hydrops [4-6]. The risk of acquiring parvovirus B19 infection during pregnancy varies between $0.61 \%$ in Belgium to $1.58 \%$ in Poland [7] and is higher during epidemics.

Parvovirus B19 is globally widespread [4], but nonetheless, the seroprevalence varies by country. The Parvovirus B19 infection is common in childhood, with seroprevalences in Europe increasing quickly through childhood and the teenage years to above $50-70 \%$, followed by a plateau in young adulthood, and another increase starting at $25-30$ years old $[7,8]$. The seroprevalence is also influenced by education, a proxy for socio-economic status [9]. In Germany, Parvovirus B19 seroprevalence in asymptomatic pregnant women varied between 65 and $70 \%$, depending on the year studied (1997-2004) [8]. The epidemic cycles are around 4 years, with 1 or 2 epidemic years, followed by 2 or 3 years of less frequent cases [8].

Transmission through respiratory droplets or by blood [1] usually occurs immediately before the clinical manifestation is present [10]. Contact with small children poses a greater risk for the parvovirus B19 infection [9] since they are more likely to drool. It is, therefore, worthwhile to investigate the risks of women working in close and frequent contact with small children, such as daycare workers or kindergarten teachers. Elsner and colleagues systematically searched and summarized research on various infections in daycare workers in 2009 [11], but to our knowledge, to this date, there has been no systematic review and meta-analysis focusing on the potential risk of parvovirus B19 in daycare workers. The aim of this study was to summarize the evidence of methodologically-adequate studies to investigate if there is an increased risk of parvovirus B19 infection for daycare workers compared to the general population and to quantify this risk. Depending on the size of the increased risk, consideration of the parvovirus B19 infection as an occupational disease in daycare workers could be made. Consequently, we performed a systematic literature review and meta-analysis of studies examining parvovirus B19 infection on daycare workers.

\section{Methods}

\subsection{Protocol and Registration}

Our review on parvovirus B19 infection is part of a comprehensive review of seroprevalences and risks for infections in daycare workers, and an update of a previously-published review on risk of infectious diseases in daycare workers [11]. The guidelines for conducting and reporting meta-analyses of observational studies in epidemiology (MOOSE) [12] and the Preferred Reporting Items for Systematic reviews and Meta-Analyses (PRISMA) [13] were followed. The study protocol was registered in PROSPERO under record number CRD42018083646 and is available at https: //www.crd.york.ac.uk/prospero/display_record.php?RecordID=83646.

\subsection{Search, Selection, and Data Extraction}

Our aim was to investigate whether daycare workers have an increased risk of a work-related parvovirus B19 infection compared to the general population. On February 14, 2018, we applied a systematic electronic literature search based on the Population, Intervention (Exposure), Control/ Comparison, Outcome (PICO) scheme [14] using the Medline and Embase databases to find studies in 
peer-reviewed journals since 2000, as an update to the previous review [11]. We updated the search on October 4, 2018. The Medline search strategy is a search for several infections, including parvovirus B19, and is shown in Figure 1.

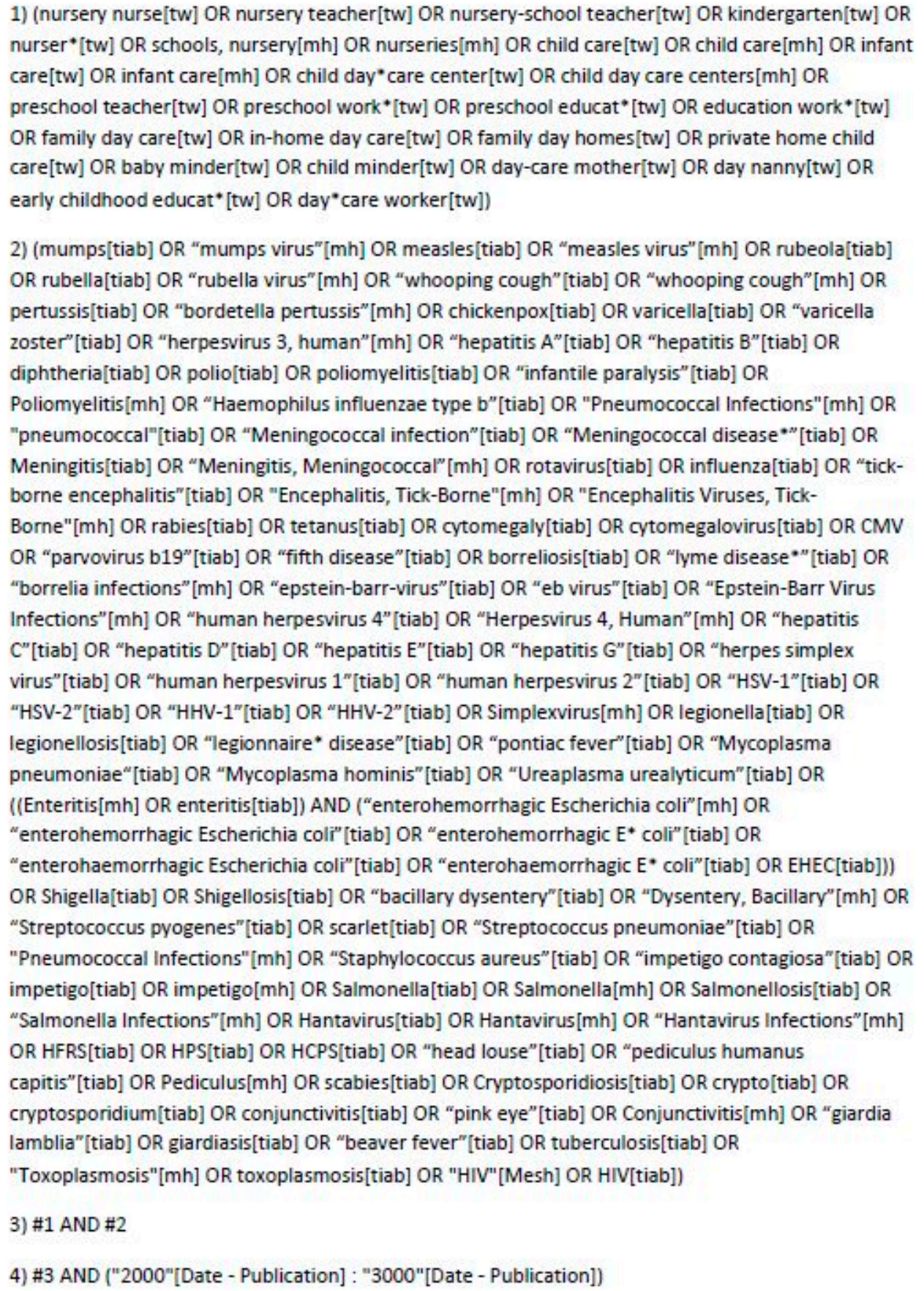

Figure 1. The Medline search strategy PubMed February 2018 (Last update 4 October 2018).

To increase the comparability of the population data, we limited the review to studies in European countries, the USA, Canada, Australia, and New Zealand. We also did not apply language restrictions with the intention to minimize reporting biases. Only cohort, case-control, or cross-sectional studies studying daycare workers between 16 and 70 years old, who worked with children up to 6 years old, were included. For risk of infection, we considered studies using comparison populations employed in other occupational groups where an average population-based risk for infection can be presumed 
(office workers or the general population), and we excluded studies using occupational groups with an elevated risk of infection as comparison populations (health care workers). We also excluded studies done in response to a disease outbreak in a child daycare center.

Our primary outcome of interest was "parvovirus B19 infection risk" which is best defined as the parvovirus B19 seroconversion rate of daycare workers compared to the unexposed population. Ideally, the daycare workers and comparison group would be tested for parvovirus B19 seropositivity at the beginning of the study. Those who were seronegative would be followed-up for a period of time and the parvovirus B19 seroconversion rates would be compared between both groups after the follow-up period. However, it is likely that many studies may not have investigated seroconversion rates. We, therefore, considered studies in which parvovirus B19 seropositivity is measured for both study groups and a cross-sectional analysis is followed using prevalence ratios or prevalence odds ratios. We also considered studies reporting only parvovirus B19 seroprevalence in daycare workers (lacking a comparison group) as the last option. Together, we considered three outcomes for our study in order of decreasing relevance: parvovirus B19 infection risks measured by seroconversion rate ratios (outcome Ia), parvovirus B19 prevalence ratios or prevalence odds ratios (outcome Ib), and parvovirus B19 seroprevalence of only daycare workers (outcome II).

Two independent scientists screened titles and abstracts of the studies in order to exclude studies unrelated to the a priori defined research questions. If there was disagreement on inclusion, a consensus decision was sought by discussion. If still no agreement was achieved, the decision was made by a third reviewer. In the manual search, we screened key articles and systematic reviews to identify further relevant studies. In addition, we used the "citation tracking factor" by Google scholar on key papers to further identify pertinent studies $[15,16]$. The full texts of the remaining studies were then thoroughly and independently examined by two reviewers to decide whether the inclusion criteria were met.

The data extraction was done by one reviewer and was checked by a second one. We discussed disagreements in consensus conferences moderated by the principal investigator (K.R.). Whenever there was missing or unclear information, we tried to obtain it through personal communication with authors. The data extraction form includes information on relevant study characteristics (first author and publication year, country of origin, exposure, outcome, study population, recruitment, confounding, analysis method, study results, conflicts of interest, and risk of bias).

\subsection{Risk of Bias Assessment}

For each included study, two reviewers assessed the risk of bias as high, low, or unclear against eight domains of bias, similar to Ijaz et al. 2013 [17] and Shamliyan et al. 2011 [18]. We also used the criteria described by SIGN (Scottish Intercollegiate Guidelines Network) [19] and CASP (Critical Appraisal Skills Programme of the British National Health Service Appraisal Tools) [20]. The eight domains of bias are presented in the Supplementary Materials.

\subsection{Overall Assessment of Risk of Bias}

For the overall assessment of the risk of bias of a study, we assigned domains into two hierarchical groups. Five domains were defined as "major domains for risk of bias": (i) recruitment procedure and follow-up (in cohort studies), (ii) exposure definition and measurement, (iii) outcome source and validation, (iv) confounding, and (v) methods of analysis. The other three domains were defined as minor domains and were (vi) chronology (in the case of seroconversion rates and infection risk outcomes), (vii) funding, and (viii) conflicts of interest. Since it is unlikely that parvovirus B19 seropositivity affects whether a person works as a daycare worker, cross-sectional studies should be acceptable in studying risk effects. We, therefore, considered chronology as a minor domain. In order for a study to have an overall low risk of bias, every major domain for risk of bias would have to be rated as low risk. If one of the major domains for risk of bias was rated as either high risk or unclear 
risk, the study was considered to have a high overall risk of bias. The detailed form is available in Supplementary Table S1.

\subsection{Statistical Analysis}

For the meta-analysis, we analyzed parvovirus B19 prevalence ratios and seroconversion rate ratios to estimate relative risks, as well as seroprevalences. We assessed statistical heterogeneity with the $\mathrm{I}^{2}$ statistic, and assessed publication bias by observing the funnel plot asymmetry and performing Egger's test to check small study bias.

\subsection{GRADE: Quality of Evidence Assessment}

We used the GRADE approach for grading the quality of the total body of evidence [21], following the examples of Ijaz et al. [17] and Kuijer et al. [22]. Four levels of quality were considered: high, moderate, low, and very low. An initial "high" level would indicate having longitudinal studies assessing seroconversion rate ratios. If only cross-sectional analyses were done, then the starting level would be set to "moderate". The quality of evidence was downgraded based on these 4 factors: study limitations (the majority of studies having a high risk of bias), inconsistency $\left(\mathrm{I}^{2}>50 \%\right)$, imprecision (range of the $\mathrm{CI}$ of studies $>2.0$ ), and publication bias (yes or unclear). Study findings with large effect sizes (an effect estimate $>1.5$ in low risk of bias studies) resulted in an upgrade of the quality of evidence.

\section{Results}

\subsection{Search Results}

The database search identified 7781 studies, and the manual search identified an additional 227 studies. After the removal of duplicates, 6879 studies were screened and 61 studies were assessed for eligibility. Of the 11 eligible studies, four studies [23-26] investigated parvovirus B19. The process flow is shown in Figure 2, and the four studies are characterized in Table 1 and below. The studies originated either in Europe [23-25] or in Canada [26]. One study investigated seroconversion rate ratios [24] (Outcome Ia) and had an overall low risk of bias, while two studies with a high risk of bias $[23,25]$ reported prevalence ratios (Outcome $\mathrm{Ib}$ ). All four studies reported parvovirus B19 seroprevalence.

The cross-sectional study of De Villemeur et al. [23] recruited 395 women working in 1 of 83 child daycare centers and 382 women employed in 1 of 2 business organizations in Isère, France, for the comparison group. The response for the daycare workers was acceptable (63\%). Although no specific information was available regarding the response of the business workers, they were required to have annual health and blood tests, where they were recruited. No refusals were reported for them (email communication with the author). This study included personnel in the exposed population who were not in regular contact with children (cleaning or administrative personnel). Parvovirus B19 seroprevalence was measured by B19 Ig G assays for both groups. The resulting seroprevalence of parvovirus B19 in childcare workers was $79.4 \%$ (Table 2), while the comparison had a prevalence of $68.0 \%$. Stratification by age resulted in a lower prevalence for women who were 37 years old or younger $(67.7 \%$, 95\% CI 59.0-75.5) than women who were older than 37 years of age $(85.4 \%, 95 \%$ CI 80.6-89.5). Using multivariate log-binomial models (adjusted by age, occupational group, number of children, duration of in-home childcare, informal child-care, number of years in a child-care facility, and residency in a low developed country) there was a slightly increased risk of infection for daycare workers compared to the business workers (Prevalence Ratio, PR $=1.05,95 \%$ CI 0.94-1.16), although it was not statistically significant.

Using retrospective data collected between 1992 and 1993 from the Finnish Maternity Cohort, Riipinen et al. [24] investigated parvovirus B19 infection risk on pregnant daycare workers. Although this study coincided with a major epidemic of parvovirus B19, it was not conducted in response to a 
disease outbreak in a child daycare center, and thus it was included. Seroprevalence was measured using early-pregnancy sera, and the cord blood.

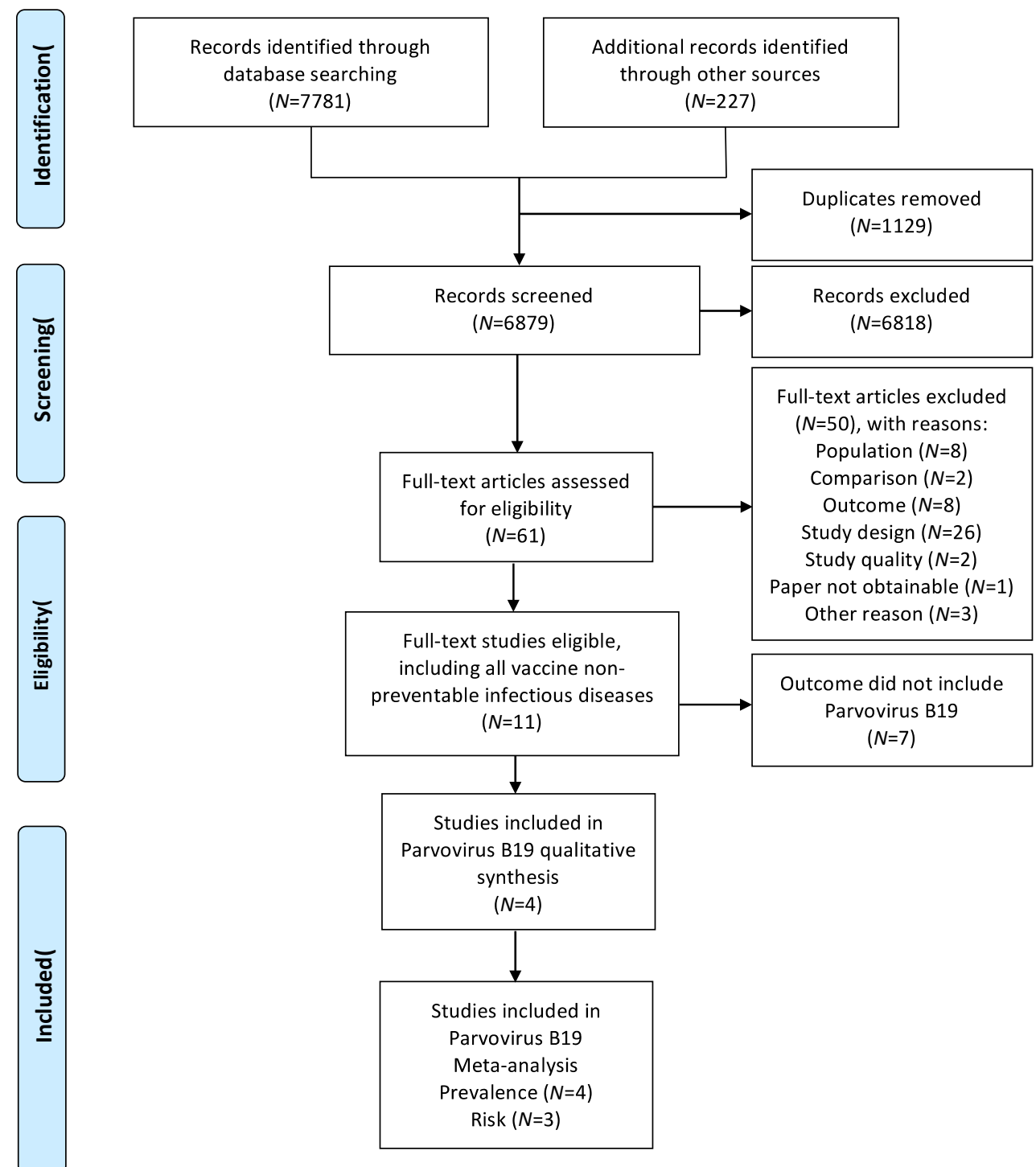

Figure 2. The study process flow. 
Table 1. The characteristics of the included studies.

\begin{tabular}{|c|c|c|c|c|c|c|c|}
\hline \multirow[b]{2}{*}{$\begin{array}{c}\text { First Author, } \\
\text { Publication Year }\end{array}$} & \multirow[b]{2}{*}{$\begin{array}{c}\text { Study } \\
\text { Region }\end{array}$} & \multirow[b]{2}{*}{ Study Design } & \multicolumn{3}{|c|}{ Population } & \multirow[b]{2}{*}{$\begin{array}{l}\text { Exposure, Duration of } \\
\text { Employment, Job Duties }\end{array}$} & \multirow[b]{2}{*}{$\begin{array}{c}\text { Outcome } \\
\text { Measurement }\end{array}$} \\
\hline & & & Sample Population & $\begin{array}{c}\text { No. of Exposed/ } \\
\text { No. of Unexposed (Response, Age) } \\
\text { Follow-up (\%) }\end{array}$ & $\begin{array}{c}\text { Time of } \\
\text { Recruitment }\end{array}$ & & \\
\hline $\begin{array}{l}\text { De Villemeur et al. } \\
\qquad 2011\end{array}$ & France & $\begin{array}{l}\text { Cross-sectional } \\
\text { study }\end{array}$ & $\begin{array}{c}\text { Women } 20-50 \text { yr, not pregnant, } \\
\text { employed in either } 1 \text { of } 83 \text { child } \\
\text { daycare centers (exposed) or in } \\
1 \text { of } 2 \text { business organizations } \\
\text { (unexposed) }\end{array}$ & $\begin{array}{c}\text { Exposed } \\
N=395 \text { (all women) } \\
\text { Age characteristics: } \\
\text { Mean: } 39.0 \mathrm{yr} \\
\text { Range: } 38.3-39.7 \mathrm{yr} \\
\text { Response: } 63.3 \% \\
\text { Not exposed } \\
N=382 \text { (all women) } \\
\text { Age characteristics: } \\
\text { Mean: } 39.3 \mathrm{yr} \\
\text { Range: } 33.1-34.8 \mathrm{yr} \\
\text { Response: N.A. }{ }^{+}\end{array}$ & 2005-2007 & $\begin{array}{l}\text { Self-administered questionnaires } \\
\text { Duration of employment: N.A. } \\
\text { Job duties: N.A. }\end{array}$ & $\begin{array}{c}\text { Blood samples } \\
\text { EIA }^{\circledR} \text { anti-B19 IgG } \\
\text { (Biotrin) }\end{array}$ \\
\hline Riipinen et al. 2014 & Finland & $\begin{array}{l}\text { Retrospective } \\
\text { cohort study }\end{array}$ & $\begin{array}{l}\text { Pregnant women from the } \\
\text { Finnish Maternity Cohort, who } \\
\text { were pregnant during } \\
\text { September 1992-August } 1993\end{array}$ & $\begin{array}{c}\text { Serological analysis (baseline) } \\
\text { Exposed } \\
N=1162 \text { (all women) } \\
\text { Age characteristics: } \\
\text { Distribution: } \\
19-24 \text { yr: } 212(10.8 \%) \\
25-29 \text { y: } 935(47.6 \%) \\
30-34 \text { yr: } 638(32.5 \%) \\
35-48 \text { yr: } 181(9.2 \%) \\
\text { Not exposed } \\
N=60 \text { (all women) } \\
\text { Age characteristics: } \\
\text { not specified, but in } \\
\text { reproductive age } \\
\text { Response: } 96.9 \% \text { (all groups) } \\
\text { Cord blood samples } \\
\text { (follow-up) } \\
\text { Exposed } \\
N=331 \\
\text { Not exposed } \\
N=60 \text { (other occupation) } \\
N=326 \text { (healthcare workers) } \\
\text { Follow-up: 56.6\% } \\
\text { (all exposure groups) }\end{array}$ & $\begin{array}{c}\text { September } \\
\text { 1992-August } 1993\end{array}$ & $\begin{array}{l}\text { Nursery school teachers identified } \\
\text { from files of Trade Union of } \\
\text { Education ( } 95 \% \text { unionization rate } \\
\text { for teachers) and the Union of } \\
\text { Professional Social Workers. } \\
\text { Other occupations identified from } \\
\text { the register of National Supervisory } \\
\text { Authority for Welfare and Health } \\
\text { To define employment-verified } \\
\text { occupation, the registers of the } \\
\text { Finnish Center for Pensions } \\
\text { were used. }\end{array}$ & $\begin{array}{l}\text { B19V IgG by an } \\
\text { indirect enzyme } \\
\text { immunoassay } \\
\text { using } \\
\text { streptavidin-bound } \\
\text { biotinylated } \\
\text { virus-like particles } \\
\text { of virus protein 2 } \\
\text { as an antigen. }\end{array}$ \\
\hline
\end{tabular}


Table 1. Cont

\begin{tabular}{|c|c|c|c|c|c|c|c|}
\hline \multirow[b]{2}{*}{$\begin{array}{c}\text { First Author, } \\
\text { Publication Year }\end{array}$} & \multirow[b]{2}{*}{$\begin{array}{l}\text { Study } \\
\text { Region }\end{array}$} & \multirow[b]{2}{*}{ Study Design } & \multicolumn{3}{|c|}{ Population } & \multirow[b]{2}{*}{$\begin{array}{l}\text { Exposure, Duration of } \\
\text { Employment, Job Duties }\end{array}$} & \multirow[b]{2}{*}{$\begin{array}{c}\text { Outcome } \\
\text { Measurement }\end{array}$} \\
\hline & & & Sample Population & $\begin{array}{c}\text { No. of Exposed/ } \\
\text { No. of Unexposed (Response, Age) } \\
\text { Follow-up (\%) }\end{array}$ & $\begin{array}{c}\text { Time of } \\
\text { Recruitment }\end{array}$ & & \\
\hline $\begin{array}{l}\text { Van Rijckevorsel } \\
\text { et al. } 2012\end{array}$ & $\begin{array}{l}\text { The } \\
\text { Netherlands }\end{array}$ & $\begin{array}{l}\text { Cross-sectional } \\
\text { study }\end{array}$ & $\begin{array}{l}\text { Childcare personnel working in } \\
38 \text { daycare centers on the } \\
\text { Amsterdam municipal register } \\
\text { (exposed), compared to women } \\
\text { not working in daycare from } \\
\text { Amsterdam Health Monitor } \\
\text { (AMH) survey (unexposed) }\end{array}$ & $\begin{array}{c}\text { Exposed } \\
N=242 \text { (all women) } \\
\text { Age characteristics: } \\
\text { Mean: } 29.0 \mathrm{yr} \\
\text { Inter-quartile range (IQR): } \\
24-35 \text { yr } \\
\text { Response: "nearly all agreed to } \\
\text { participate" }(\sim 100 \%) \\
\text { Not exposed } \\
N=298 \text { (all women) } \\
\text { Age characteristics: } \\
\text { Mean: } 35 \mathrm{yr} \\
\text { IQR: } 28-40 \mathrm{yr} \\
\text { Response }=43.8 \%\end{array}$ & $\begin{array}{c}\text { Daycare center } \\
\text { employees: } 2007 \\
\text { Unexposed group: } \\
2004\end{array}$ & $\begin{array}{c}\text { Face interviews and through a } \\
\text { cross-sectional survey in } 2007 \text { by } \\
\text { the Public Health Service of } \\
\text { Amsterdam } \\
\text { Duration of employment: } \\
\text { N.A. } \\
\text { Job duties: } \\
\text { N.A. }\end{array}$ & $\begin{array}{c}\text { Blood samples } \\
\text { NovaLisa } \\
\text { Parvovirus B19 } \\
\text { recombinant IgG } \\
\text { ELISA }{ }^{\ddagger}\end{array}$ \\
\hline Gilbert et al. 2005 & Canada & $\begin{array}{l}\text { Cross-sectional } \\
\text { study }\end{array}$ & $\begin{array}{c}\text { Educators working in daycare } \\
\text { centers which were in current } \\
\text { operation, enrolled children } \\
\text { under } 36 \text { months and employed } \\
\text { at least six educators. } \\
\text { Educators had to be employed } \\
\text { for at least } 15 \mathrm{~h} / \text { week and cared } \\
\text { for children }<60 \text { months of age. }\end{array}$ & $\begin{array}{c}\text { Exposed } \\
N=477 \text { (all women) } \\
\text { Age characteristics:Mean: } 34 \text { years } \\
\text { Range: } 17-70 \text { years } \\
<50 \text { yr }(91 \%) \\
\text { Response at daycare level: } 53.3 \% \\
\text { Individual response: } \\
44.3 \%\end{array}$ & $\begin{array}{c}\text { October-December } \\
2001\end{array}$ & $\begin{array}{l}\text { Questionnaires sent to directors } \\
\text { and educators } \\
\text { Duration of employment } \\
<5 \text { yr: } n=162(34.0 \%) \\
5-9 \text { yr: } n=132(27.7 \%) \\
10-14 \text { yr: } n=106(22.3 \%) \\
\geq 15 \text { yr: } n=76(16.0 \%)\end{array}$ & $\begin{array}{l}\text { ELISA parvovirus } \\
\text { B19 IgG } \\
\text { Biotrin } \\
\text { International Ltd., } \\
\text { Dublin, Ireland }\end{array}$ \\
\hline N.A. $=$ not avail & 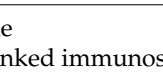 & nt assay & & & & & \\
\hline
\end{tabular}


Table 2. The summary of the parvovirus B19 seroprevalence and risk estimates for daycare workers.

\begin{tabular}{|c|c|c|c|c|c|c|c|}
\hline \multirow[b]{2}{*}{ Study ID } & \multicolumn{4}{|c|}{ Risk Estimates (Outcomes Ia and Ib) } & \multicolumn{3}{|c|}{ Seroprevalence Estimates (Outcome II) } \\
\hline & Effect Estimate & Effect Value & Adjusted for & Further Analysis & $\begin{array}{c}\text { Age } \\
\text { Category } \\
\end{array}$ & $\begin{array}{c}\text { Seroprevalence, \% in } \\
\text { Daycare Workers }\end{array}$ & Other Analysis \\
\hline \multirow{3}{*}{$\begin{array}{l}\text { De Villemeur et al. } \\
2011\end{array}$} & \multirow{3}{*}{$\begin{array}{c}\mathrm{PR}^{+} \\
\text {(Outcome Ib) }\end{array}$} & \multirow{3}{*}{$\begin{array}{c}1.05 \\
(0.94-1.16)\end{array}$} & \multirow{3}{*}{$\begin{array}{l}\text { Age, occupational group, number of } \\
\text { own children, attendance/duration of } \\
\text { in-home childcare and/or informal } \\
\text { child-care and/or child-care facility, } \\
\text { and residence in a country of } \\
\text { low/medium economic development }\end{array}$} & \multirow{3}{*}{ - } & all & $79.4(75.1-83.3)$ & \multirow{3}{*}{-} \\
\hline & & & & & $\leq 37$ years & $67.7(59.0-75.5)$ & \\
\hline & & & & & $>37$ years & $85.4(80.6-89.5)$ & \\
\hline \multirow{3}{*}{ Riipinen et al. 2014} & \multirow{3}{*}{$\begin{array}{c}\mathrm{HR} \ddagger \\
\text { (Outcome Ia) }\end{array}$} & \multirow{3}{*}{$\begin{array}{c}\text { Daycare worker } \\
\text { HR }=2.63 \\
(1.27-5.46) \\
\text { Other occupation } \\
\text { HR }=0.85 \\
(0.18-4.09) \\
\text { Reference: health } \\
\text { care workers }\end{array}$} & \multirow{3}{*}{$\begin{array}{l}\text { Age, employment, number of } \\
\text { children, high infection risk period, } \\
\text { capital region }\end{array}$} & \multirow{3}{*}{$\begin{array}{c}\text { Nulliparous } \\
\text { women only: } \\
\text { HR }=5.59 \\
(1.40-22.4)\end{array}$} & all & $59.1(56.9-61.3)$ & \multirow{3}{*}{-} \\
\hline & & & & & $19-34$ years & $58.9(56.6-61.2)$ & \\
\hline & & & & & $35-48$ years & $61.3(53.8-68.5)$ & \\
\hline $\begin{array}{l}\text { Van Rijckevorsel } \\
\text { et al. } 2012\end{array}$ & $\begin{array}{c}\mathrm{PR}^{+} \\
\text {(Outcome Ib) }\end{array}$ & $\begin{array}{c}1.2 \\
(1.1-1.4)\end{array}$ & Age, country of birth, having children & - & all & $72.2(66.7-78.2)$ & - \\
\hline \multirow{3}{*}{$\begin{array}{l}\text { Gilbert } \\
\text { et al. } 2005\end{array}$} & \multirow{3}{*}{-} & \multirow{3}{*}{-} & \multirow{3}{*}{-} & \multirow{3}{*}{-} & all & $69.8(65.5-73.9)$ & \multirow{3}{*}{$\begin{array}{c}\text { Seroprevalence by experience in daycare: } \\
\text { <5 yr: 61.1\% } \\
(95 \% \text { CI } 53.1-68.7) \\
5-9 \text { yr: } 71.2 \%(95 \% \text { CI } 62.7-78.8) \\
10-14 \text { yr: } 75.5 \%(95 \% \text { CI } 66.2-83.3) \\
\geq 15 \text { yr: } 77.6 \% \\
(95 \% \text { CI } 66.6-86.4)\end{array}$} \\
\hline & & & & & $\leq 34$ years & $64.6(58.2-70.6)$ & \\
\hline & & & & & $>34$ years & $75.5(69.5-81.0)$ & \\
\hline $\begin{array}{l}{ }^{\dagger} \text { Prevalence Ratio } \\
\ddagger \text { Hazard Ratio }\end{array}$ & & & & & & & \\
\hline
\end{tabular}


Samples of seronegative women were tested for seroconversion during pregnancy. Although the authors used healthcare workers as the reference group to estimate the increased risk of daycare workers, they also included another comparison group "other occupations", which can be used to indirectly compare the daycare workers to the general population. The inclusion of both comparison groups thus qualified Riipinen et al. for inclusion. For the reporting of seroprevalence, education (daycare education or healthcare education) was used as a proxy for occupation. For seroconversions, occupations were identified from the files of professional unions and verified through the register of the Finnish Center for Pensions, and the duration of employment was provided. The study is characterized by a large sample size with a high response and an acceptable loss to follow-up. Pregnant daycare workers had a 59.1\% B19 parvovirus seroprevalence, while $54.9 \%$ of pregnant healthcare workers were seropositive. There was no information given on the seroprevalence of pregnant workers in other occupations. Seroprevalence increased slightly with age. The daycare workers had an annual seroconversion rate of $12.2 \%$, while those in healthcare had annual seroconversion rates of $6.7 \%$. Compared to healthcare workers, daycare workers had a higher rate for infection (HR $=2.63,95 \% \mathrm{CI}$ 1.27-5.46), and workers in other professions were at a decreased risk of infection compared to healthcare workers ( $\mathrm{HR}=0.85,95 \% \mathrm{CI} 0.18-4.09)$. When the analysis was restricted to nulliparous women with no childcare leave, the risk of infection for daycare workers compared to healthcare workers increased (HR $=5.59,95 \%$ CI 1.40-22.4).

In a cross-sectional study, van Rijckevorsel et al. 2012 [25] studied the parvovirus B19 seroprevalence among 242 females working in one of 38 randomly-sampled daycare centers in 2007 in Amsterdam, measured by parvovirus B19 IgG ELISA. Their risk of infection was compared to women who participated in a cross-sectional survey of the Amsterdam population (Amsterdam Health Monitor, AHM) in 2004. The response of daycare centers was appropriate (60\%), and it was reported that nearly all daycare workers had agreed to participate. The AHM response (including available blood samples) was low $(43.8 \%)$ and was lowest for the youngest age group (18-34 years) [27,28]. Parvovirus B19 seroprevalence for daycare workers was $72.7 \%$, while the comparison group had a $60.4 \%$ seroprevalence. A multivariate binomial regression analysis adjusting for age, country of birth, and having children resulted in an increased prevalence ratio for daycare workers compared to the AHM population ( $\mathrm{PR}=1.2,95 \% \mathrm{CI} 1.1-1.4$ ). No adjustment was done for socioeconomic status.

Educators working in 2001 in Canadian daycare centers which enrolled children under 36 months were studied by Gilbert et al. [26]. To be eligible, the educators must have worked for at least $15 \mathrm{~h} \mathrm{a}$ week caring for children less than 60 months of age. The response was low, and a substantial differential selection of the study population could not be excluded. Through questionnaires, characteristics of the daycare workers, including their duration of employment, were obtained. The overall seroprevalence for daycare workers was $69.8 \%$ (95\% CI 65.5-73.9), and seroprevalence appeared to increase with age and with increasing experience in daycare.

A summary of the studies' risk of bias is presented in Figure 3, and a synopsis of their effect estimates is shown in Table 2. 


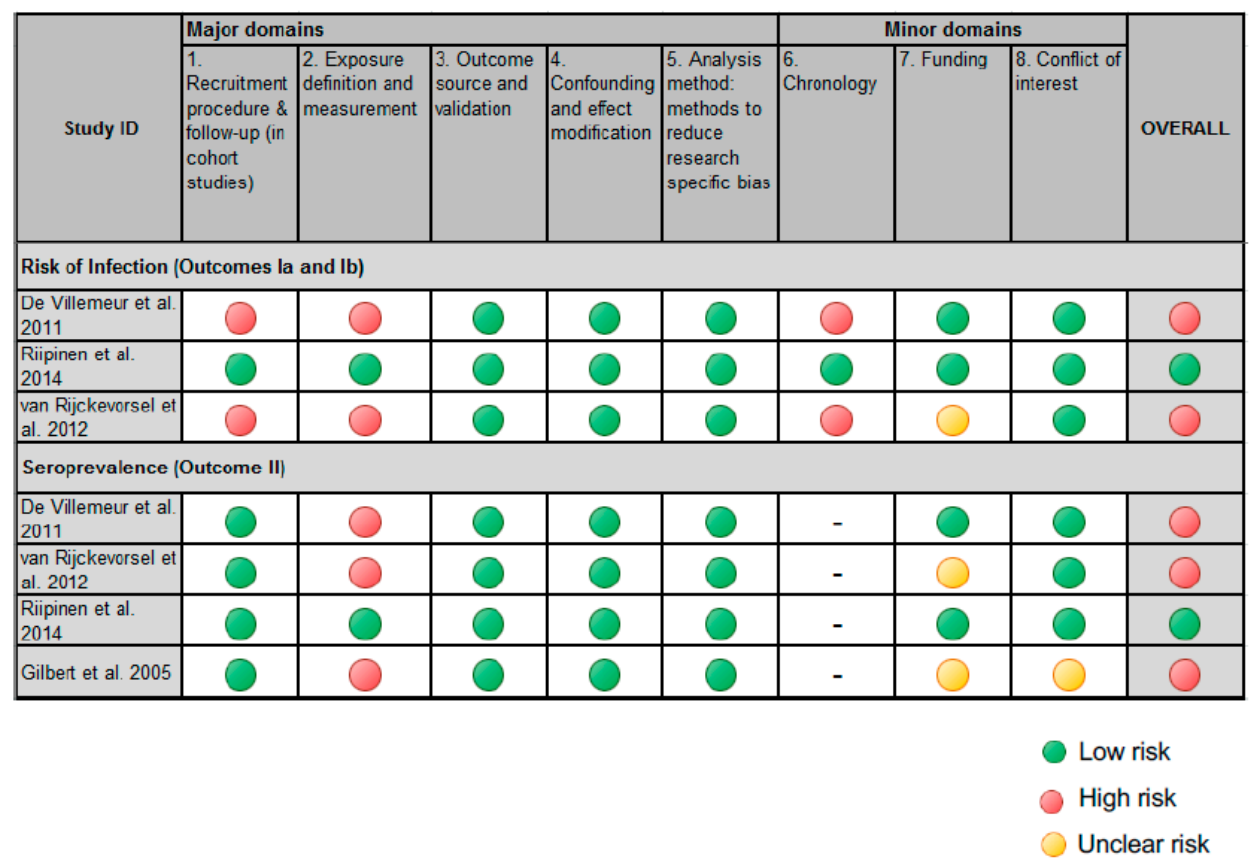

Figure 3. The risk of bias of the included studies.

\subsection{Risk of Infection (Outcomes Ia and Ib)}

Only one study [24] providing the seroconversion risk ratio (outcome Ia) of daycare workers compared to another population was identified. Two other studies [23,25] presented prevalence ratios. We compared the studies presenting PRs (also with high risks of bias) with the study providing a seroconversion risk ratio (low risk of bias). The pooled relative risk for the studies reporting PRs was 1.12 (95\% CI 0.98-1.27), much lower than the one reporting the seroconversion risk ratio RR 2.63 (95\% CI 1.27-5.45) (Figure 4).

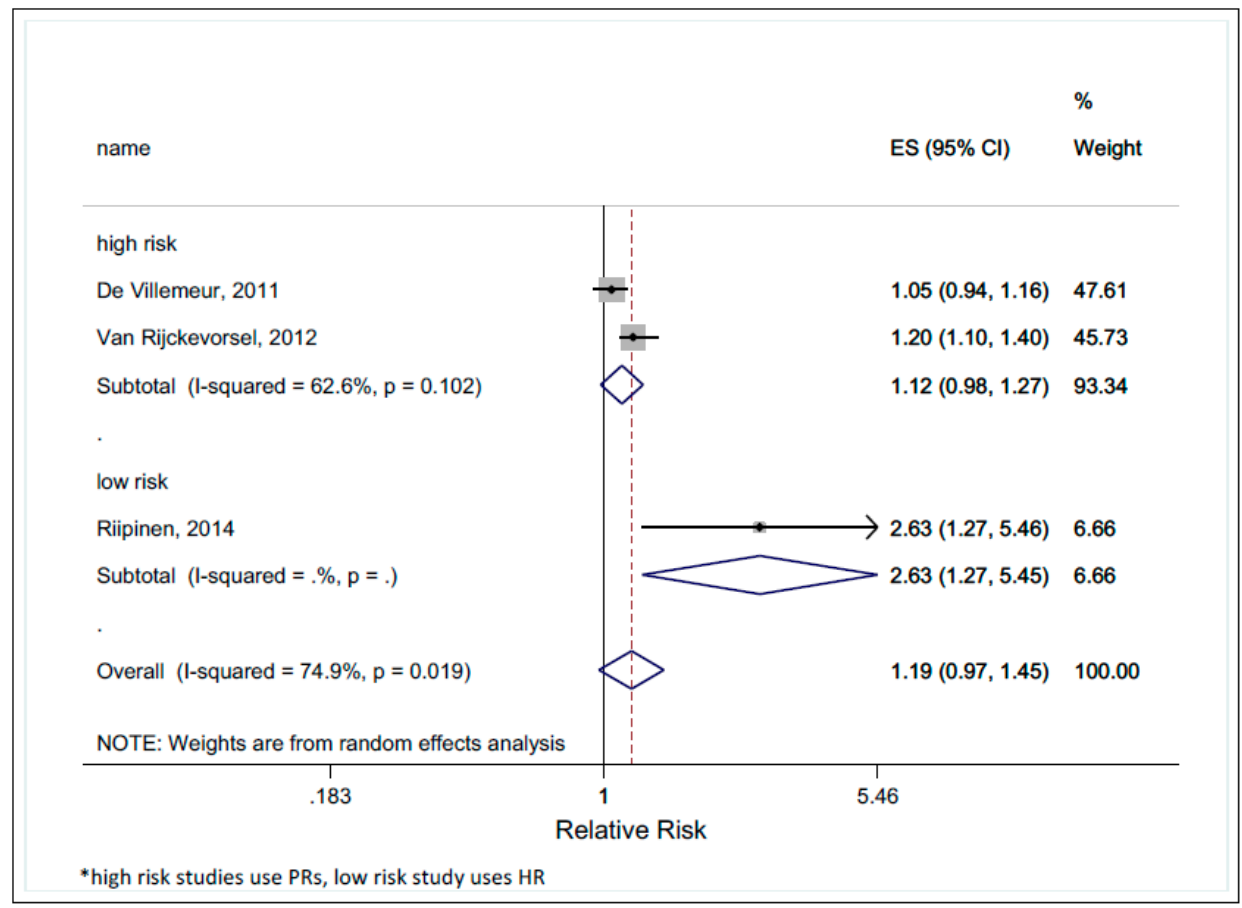

Figure 4. The effect size (ES) of relative risk by study's risk of bias. 
The funnel plot did not show evidence of publication bias (Figure S1 in Supplementary Materials), and the Egger's test was not significant (Egger's coefficient $=2.92,95 \% \mathrm{CI}-17.5-23.4, p=0.32$ ).

\subsection{Parvovirus B19 Seroprevalence (Outcome II)}

All four studies were included in the meta-analysis for seroprevalence. The overall prevalence of parvovirus B19 in daycare workers for the four included studies was 70.2\% (95\% CI 59.9-80.4) and heterogeneous $\left(\mathrm{I}^{2}=96.5 \%\right)$. To study whether the variation between studies might be due to age differences in the study populations, we analyzed older and younger populations separately. Van Rijckevorsel [25] did not categorize by age, and they were excluded from this analysis. De Villemeur [23] stratified their results by two age categories ( $\leq 37$ vs $>37$ years), and we categorized each as "younger" or "older", respectively. The results of the rest of the studies could be categorized by age in a similar way ( $\leq 34$ years "younger" vs. $>34$ years "older"). The pooled prevalence for the younger population was $62.7 \%\left(95 \%\right.$ CI $\left.57.2-68.3, \mathrm{I}^{2}=68.5 \%\right)$, and that for the older population was $74.4 \%(95 \%$ CI $61.2-87.5$, $\left.\mathrm{I}^{2}=93.6 \%\right)$. The pooled seroprevalence for the high risk of bias studies $[23,25,26]$ was $74.1 \%(95 \% \mathrm{CI}$ $\left.67.9-80.3, \mathrm{I}^{2}=81.2 \%\right)$, while the low risk of bias study [24] had a seroprevalence of $59.1 \%(95 \% \mathrm{CI}$ 56.9-61.3). The forest plots for seroprevalence are available in the Supplementary Materials (Figures S2 and S3).

After starting our GRADE evaluation at "high", we judged that the quality of evidence for risk of infection of daycare workers to be "moderate". The majority of studies had a high risk of bias and there was a high inconsistency between the studies. However, the imprecision in the studies was acceptable, and the effect estimate in the low risk of bias study was greater than 1.5.

\section{Discussion}

To our knowledge, this is the first comprehensive systematic review on the parvovirus B19 infection on daycare workers since 2009. Altogether, we found moderate evidence of an increased parvovirus B19 seroprevalence for daycare workers compared to the unexposed population.

We also found the parvovirus B19 seroprevalence for daycare workers to be $70 \%$.

Analysis of seroprevalence by age revealed a lower seroprevalence for younger workers compared to their older counterparts. In Germany, the parvovirus B19 seroprevalence has been reported to be at $20 \%$ in 1 to 3 -year-old children, and at $67 \%$ in adolescents, rising to $72 \%$ in adulthood to $79.1 \%$ in the elderly [29].

\subsection{Agreement with Other Studies and Reviews}

The previous review by Elsner et al. [11] also concluded that daycare workers were at a higher risk for parvovirus B19 infection even if our inclusion criteria differed significantly, in particular, with respect to our more stringent criteria regarding the exposure definition, exclusion of studies done as a result of an outbreak, and recruitment procedure. Because Elsner et al. investigated studies published before 2009, and due to our differing criteria, there was no overlap in studies between both reviews other than a cross-sectional study on parvovirus B19 seroprevalence [26].

\subsection{Strengths and Limitations}

The main strengths of our research methods were the systematic literature search using a comprehensive search string in two databases (Medline and Embase), the independent appraisal of titles, abstracts, and full texts by two researchers, and the dual assessment of study quality with consensus finding to determine the final quality score in case of disagreements. We performed a formal risk of bias assessment for the studies and integrated these assessments for our analysis and conclusions. Because no reliable information about the infection risk or prevalence of a definable population can be determined, studies using a convenience sample were excluded. Similarly, studies with no information on the response (\%) were excluded due to the potential for selection bias. Furthermore, only peer-reviewed articles published in scientific journals were included. The resulting 
exclusion of the grey literature could mean a loss of information. However, including studies with inadequate quality would have introduced bias.

We excluded studies that were unclear as to whether the person was working in a daycare center setting or as a childminder with children up to six years old. Such studies may have introduced other exposed populations, such as healthcare workers working with children.

\subsection{The Methodological Quality of Included Studies}

Only one of the four included studies were assessed as having a low risk of bias. Studies were rated with a high risk of bias mainly due to two domains: recruitment procedure and exposure definition. Several studies either had low responses in either the exposed or unexposed populations, or the information was not provided. In addition, there were studies in which the exposed population comprised of both daycare workers in contact with children and other daycare workers with no contact with children (such as administrators or cleaning staff). This misclassification of the exposure could have resulted in an underestimation of the risk for daycare workers. In other studies, no information on the job duties or duration of employment was collected, both of which could have explained differing seroprevalence within and between the populations. Furthermore, one of the studies [25] investigating relative risks of infection did not adjust for socioeconomic status. Although the unexposed population used in this study was based on the general population, there still may have been socioeconomic differences between the daycare workers and the unexposed population. Two studies investigated the risk of infection of daycare workers compared to an unexposed population using a cross-sectional analysis. In these studies, no difference between parvovirus B19 immunity and a fresh infection could be made because IgM was not measured.

There is merit in a further discussion of Riipinen et al. 2014 as the authors used seroconversion rate ratios to compare risks between daycare workers and two other populations: healthcare workers (the reference group) and "other occupations". Daycare workers had more than twice the seroconversion rate than healthcare workers, while those in "other occupations" had a 15\% lower rate than healthcare workers. Because healthcare workers are already more at risk than the general population ("other occupations"), the reported risk ( $R R=2.63)$ is underestimated and the actual risk of daycare workers compared to the general population will be higher.

We should also address the pooled size of effect estimated by prevalence ratios in two out of three studies $[23,25]$. It is important to note that parvovirus B19 seroprevalence in the late teen or young adulthood years, at the start of the women's working life, is already high. The seroconversion risk will likely be underestimated when using prevalence ratios because the "non-occupational" seroprevalence cannot be removed from the prevalence-based "occupational" risk estimates. As an example, if an unexposed group had a parvovirus B19 seroprevalence of $65 \%$, then the daycare workers would have a seroprevalence of $72.8 \%$, assuming a PR of 1.12 (pooled from both studies reporting PRs as seen in Figure 3). If we would subtract $60 \%$ (a reasonable estimate of seropositivity at the start of the working life $[7,8,29]$ ) from both groups, we would obtain a seroconversion of $5 \%$ for the unexposed group and $12.8 \%$ for the daycare workers, which would, in turn, result in a risk effect greater than 2.5 . In order to be considered an occupational disease, the risk of infection for the exposed group should be at least double than that of the unexposed group, corresponding to at least a $50 \%$ probability of causation. Taking the above examples, our results show the potential of parvovirus B19 infection as an occupational disease for daycare workers.

A German study [30] estimated that 1.4 deaths and 1.7 cases of hydrops fetalis would be prevented by an employment ban of seronegative pregnant women working in daycares with children below six years of age until the 34th week of pregnancy. An aggressive hygiene campaign stressing frequent handwashing and cleaning of contaminated surfaces could also reduce the risk of parvovirus B19 infection. 


\subsection{Implications for Practice and Research}

This review points to a higher risk of parvovirus B19 infection workers compared to a comparison population. After adjustment for confounders such as age, socio-economic status (SES), and having one's own children, the low-risk of bias study showed a higher risk of seroconversion for daycare workers compared to a comparison population. Cross-sectional studies also point to a higher risk of infection. Since there is no vaccine available, informing daycare workers of their immunity status, raising awareness of the potential risk of infection in women trying to conceive or during pregnancy, and reinforcing prevention measures such as washing hands regularly and cleaning of contaminated surfaces may decrease the risk of infection. In case of a confirmed pregnancy in a seronegative daycare worker, necessary precautions should be taken to prevent infection. Considering the underestimation of the occupational seroconversion risk by prevalence-based estimators, parvovirus B19 infections among daycare workers might mostly be occupationally acquired.

\section{Conclusions}

Our findings suggest a higher risk of parvovirus B19 infection for daycare workers compared to an unexposed comparison population, which necessitate preventative efforts. Considering the underestimation of the occupational seroconversion risk by prevalence-based estimators, parvovirus B19 infections among daycare workers might mostly be occupationally acquired.

Supplementary Materials: The following are available online at http://www.mdpi.com/1660-4601/16/8/1392/s1, Table S1: Risk of bias form; Figure S1: Funnel plot of studies in meta-analysis; Figure S2: Parvovirus B19 seroprevalence (\%) of all included studies; Figure S3: Parvovirus B19 seroprevalence (\%) by age.

Author Contributions: The requirements for authorship have been met by all of the authors, and contributing in the following way: Conceptualization, A.F., M.S., M.K., J.S., A.N., J.H. and A.S.; Methodology, K.R.S., M.K., M.L.G., S.S. and A.S.; Software, K.R.S.; Validation K.R.S., M.K., S.S., M.L.G. and A.S.; Formal Analysis, K.R.S.; Investigation, K.R.S., M.K. and S.S.; Writing-Original draft preparation, K.R.S.; Writing-Review \& Editing, K.R.S., A.F., M.S., M.K., J.S., A.N., J.H. and A.S.; Visualization, K.R.S.; Supervision, A.S.; Project administration, A.S.; Funding acquisition, A.S.

Funding: This project was funded by the German Institution for Statutory Accident Insurance and Prevention in the Health and Welfare Services (BGW).

Conflicts of Interest: The authors declare no conflict of interest.

\section{References}

1. Young, N.S.; Brown, K.E. Parvovirus B19. N. Engl. J. Med. 2004, 350, 586-597. [CrossRef] [PubMed]

2. Crane, J. Society of Obstetricians and Gynaecologists of Canada. Parvovirus B19 infection in pregnancy. J. Obstet. Gynaecol. Can. 2002, 24, 727-743. [PubMed]

3. Koch, W.C.; Harger, J.H.; Barnstein, B.; Adler, S.P. Serologic and virologic evidence for frequent intrauterine transmission of human parvovirus B19 with a primary maternal infection during pregnancy. Pediatr. Infect. Dis. J. 1998, 17, 489-494. [CrossRef] [PubMed]

4. Koch-Institut, R. Parvovirus B19. Bundesgesundheitsblatt 2010, 53, 944-956.

5. Giorgio, E.; De Oronzo, M.A.; Iozza, I.; Di Natale, A.; Cianci, S.; Garofalo, G.; Giacobbe, A.M.; Politi, S. Parvovirus B19 during pregnancy: A review. J. Prenat. Med. 2010, 4, 63-66. [PubMed]

6. Handbuch, D. 111 parvovirus-B19-infektionen. In DGPI Handbuch, 7th ed.; Berner, R., Bialek, R., Forster, J., Härtel, C., Heininger, U., Huppertz, H.-I., Liese, J.G., Nadal, D., Simon, A., Eds.; Georg Thieme Verlag: Stuttgart, Germany, 2018.

7. Mossong, J.; Hens, N.; Friederichs, V.; Davidkin, I.; Broman, M.; Litwinska, B.; Siennicka, J.; Trzcinska, A.; Van Damme, P.; Beutels, P.; et al. Parvovirus B19 infection in five European countries: Seroepidemiology, force of infection and maternal risk of infection. Epidemiol. Infect. 2008, 136, 1059-1068. [CrossRef]

8. Enders, M.; Weidner, A.; Enders, G. Current epidemiological aspects of human parvovirus B19 infection during pregnancy and childhood in the western part of Germany. Epidemiol. Infect. 2007, 135, 563-569. [CrossRef] 
9. Valeur-Jensen, A.; Pedersen, C.B.; Westergaard, T.; Jensen, I.P.; Lebech, M.; Andersen, P.K.; Aaby, P.; Pedersen, B.N.; Melbye, M. Risk factors for parvovirus B19 infection in pregnancy. JAMA 1999, 281, 1099-1105. [CrossRef] [PubMed]

10. Gilbert, G. Parvovirus B19 infection and its significance in pregnancy. Commun. Dis. Intell. 2000, $24,69-71$. [PubMed]

11. Elsner, G.; Petereit-Haack, G.; Nienhaus, A. Berufsbedingte infektionen bei erzieherinnen und erziehern in kindergärten. Zentralbl. Arbeitsmed. Arbeitsschutz Ergonomie 2009, 59, 39-42.

12. Stroup, D.F.; Berlin, J.A.; Morton, S.C.; Olkin, I.; Williamson, G.D.; Rennie, D.; Moher, D.; Becker, B.J.; Sipe, T.A.; Thacker, S.B.; et al. Meta-analysis of observational studies in epidemiology: A proposal for reporting. JAMA 2000, 283, 2008-2012. [CrossRef] [PubMed]

13. Moher, D.; Liberati, A.; Tetzlaff, J.; Altman, D.G.; The PRISMA Group. Preferred reporting items for systematic reviews and meta-analyses: The prisma statement. PLoS Med. 2009, 6, 264-269. [CrossRef]

14. Higgins, J.; Green, S. Cochrane Handbook for Systematic Reviews of Interventions; The Cochrane Collaboration: London, UK, 2011.

15. Bakkalbasi, N.; Bauer, K.; Glover, J.; Wang, L. Three options for citation tracking: Google scholar, Scopus and Web of Science. Biomed. Digit. Libr. 2006, 3, 7. [CrossRef] [PubMed]

16. Giles, J. Science in the web age: Start your engines. Nature 2005, 438, 554. [CrossRef]

17. Ijaz, S.; Verbeek, J.; Seidler, A.; Lindbohm, M.-L.; Ojajärvi, A.; Orsini, N.; Costa, G.; Neuvonen, K. Night-shift work and breast cancer-A systematic review and meta-analysis. Scand. J. Work Environ. Health 2013, 39, 431-447. [CrossRef] [PubMed]

18. Shamliyan, T.A.; Kane, R.L.; Ansari, M.T.; Raman, G.; Berkman, N.D.; Grant, M.; Janes, G.; Maglione, M.; Moher, D.; Nasser, M.; et al. Development quality criteria to evaluate nontherapeutic studies of incidence, prevalence, or risk factors of chronic diseases: Pilot study of new checklists. J. Clin. Epidemiol. 2011, 64, 637-657. [CrossRef] [PubMed]

19. Scottish Intercollegiate Guidelines Network. Available online: https://www.sign.ac.uk/checklists-and-notes. html (accessed on 27 March 2019).

20. Critical Appraisal Skills Programme. Available online: https://casp-uk.net/casp-tools-checklists/ (accessed on 27 March 2019).

21. Guyatt, G.; Oxman, A.D.; Akl, E.A.; Kunz, R.; Vist, G.; Brozek, J.; Norris, S.; Falck-Ytter, Y.; Glasziou, P.; Jaeschke, R. Grade guidelines: 1. Introduction-Grade evidence profiles and summary of findings tables. J. Clin. Epidemiol. 2011, 64, 383-394. [CrossRef] [PubMed]

22. Kuijer, P.P.F.M.; Verbeek, J.H.; Seidler, A.; Ellegast, R.; Hulshof, C.T.J.; Frings-Dresen, M.H.W.; van der Molen, H.F. Work-relatedness of lumbosacral radiculopathy syndrome: Review and dose-response meta-analysis. Neurology 2018, 91, 558-564. [CrossRef] [PubMed]

23. De Villemeur, A.B.; Gratacap-Cavallier, B.; Casey, R.; Baccard-Longere, M.; Goirand, L.; Seigneurin, J.M.; Morand, P. Occupational risk for cytomegalovirus, but not for parvovirus B19 in child-care personnel in France. J. Infect. 2011, 63, 457-467. [CrossRef] [PubMed]

24. Riipinen, A.; Sallmen, M.; Hedman, L.; Ojajarvi, A.; Lindbohm, M.L.; Meriluoto, M.; Surcel, H.M.; Taskinen, H.; Nuutila, M.; Karikoski, R.; et al. Increased risk of human parvovirus B19 infection in day-care employees: A cohort study among pregnant workers during an epidemic in Finland. Occup. Environ. Med. 2014, 71, 836-841. [CrossRef] [PubMed]

25. Van Rijckevorsel, G.G.; Bovee, L.P.; Damen, M.; Sonder, G.J.; van der Loeff, M.F.S.; van den Hoek, A. Increased seroprevalence of IgG-class antibodies against cytomegalovirus, parvovirus B19, and varicella-zoster virus in women working in child daycare. BMC Public Health 2012, 12, 475. [CrossRef]

26. Gilbert, N.L.; Gyorkos, T.W.; Beliveau, C.; Rahme, E.; Muecke, C.; Soto, J.C. Seroprevalence of parvovirus B19 infection in daycare educators. Epidemiol. Infect. 2005, 133, 299-304. [CrossRef] [PubMed]

27. Fassaert, T.; De Wit, M.A.; Verhoeff, A.P.; Tuinebreijer, W.C.; Gorissen, W.H.; Beekman, A.T.; Dekker, J. Uptake of health services for common mental disorders by first-generation Turkish and Moroccan migrants in The Netherlands. BMC Public Health 2009, 9, 307. [CrossRef] [PubMed]

28. De Wit, M.A.S.; Tuinebreijer, W.C.; Dekker, J.; Beekman, A.-J.T.F.; Gorissen, W.H.M.; Schrier, A.C.; Penninx, B.W.J.H.; Komproe, I.H.; Verhoeff, A.P. Depressive and anxiety disorders in different ethnic groups. Soc. Psychiatry Psychiatr. Epidemiol. 2008, 43, 905-912. [CrossRef] [PubMed] 
29. Röhrer, C.; Gärtner, B.; Sauerbrei, A.; Böhm, S.; Hottenträger, B.; Raab, U.; Thierfelder, W.; Wutzler, P.; Modrow, S. Seroprevalence of parvovirus B19 in the German population. Epidemiol. Infect. 2008, 136, 1564-1575. [CrossRef] [PubMed]

30. Gärtner, B.; Enders, M.; Luft-Duchow, C.; Bocharov, G.; Modorow, S. Parvovirus-B19-infektionen bei schwangeren in der kinderbetreuung. Bundesgesundheitsblatt-Gesundheitsforschung-Gesundheitsschutz 2007, 50, 1369. [CrossRef] [PubMed]

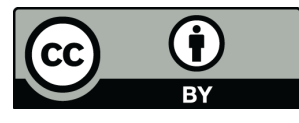

(C) 2019 by the authors. Licensee MDPI, Basel, Switzerland. This article is an open access article distributed under the terms and conditions of the Creative Commons Attribution (CC BY) license (http://creativecommons.org/licenses/by/4.0/). 